\title{
WMPLOI DU MAÏS COMME SEULE CÉRÉALE DANS L'Alimentation Des porcs Charcutiers : APPORT DE DEUX SOURCES DE GELLULOSE EN ALIMENTATION « SEMI AD Libitum », PUIS EN DISTRIBUTion « PLAFonnéE »
}

\author{
J. MOAL \\ Association générale des Producteurs de Mais, \\ $64-P a u$ \\ RÉSUMÉ
}

Dans une première expérience, l'auteur avait essayé, chez le porc charcutier, en alimentation semi ad libitum, l'incorporation à deux niveaux de farine de luzerne déshydratée (5 et Io p. IOo) ou de son de blé (ro et 20 p. roo) dans une ration de type "mais + tourteau de soja cuit " à I 8 p. Ioo de matières azotées brutes (MAB). De plus, un régime avec ıo p. Ioo de son ne contenait que 16 p. Ioo de MAB.

Ce dernier régime a donné les plus manvais résultats de composition corporelle. Tous les autres traitements sont plus mauvais que le témoin (composition corporelle et indice de consommation) exception faite de celui contenant Io p. Ioo de son et 18 p. Ioo de $M A B:$ même indice de consommation, carcasses meilleures.

Dans une deuxième expérience, l'auteur reprend tous les régimes précités, sauf le dernier. Cette fois, la distribution d'aliment est plafonnée à 2,1 $\mathrm{kg}$ par jour.

La composition corporelle est sensiblement identique pour tous les animaux, mais l'indice de consommation (IC) est très nettement en faveur du témoin (3,or contre 3,2I à 3,58). L'avantage du son au taux le plus faible ne se retrouve que très partiellement $(\mathrm{IC}=3,2 \mathrm{I}$; autres traitements : $3,4^{6}$ à 3,58 ).

L'auteur en conclut que l'adjonction de matières cellulosiques dans un régime "maïs + soja" est inutile; le son à taux modéré peut cependant se justifier en "préengraissement *.

\section{SUMMARY}

\section{MAIZE AS SOLE CEREAL, IN THE GROWING-FINISHING PIG DIETS : DISTRIBUTION OF TWO SOURCES OF CELLULOSE DURING SEMI-AD LIBITUM FEEDING FOLLOWED BX LIMITED FEEDING}

During the first trial, the author, using growing-finishing pigs submitted to semi-ad lıbitum feeding, studied the effect of adding dehydrated alfalfa (at two levels : 5 and ro p. roo) or wheat bran (Io and $20 \mathrm{p}$. Ioo) to a ration of the type " maize + cooked soybean oil meal " containing I 8 p. Ioo crude protein (CP). Moreover, one of the diets with ro p. Ioo wheat bran contained only I6 p. I $00 \mathrm{CP}$. 
This last diet gave the most unfavourable results as for body composition. The results of all the other treatments were less good as those obtained with the control diet (body composition and food conversion ratio) except in the case where the ration contained ro p. Ioo wheat bran and I 8 p. roo CP : same food conversion ratio, batter carcasses.

During the second trial, the author usad all the precited diets, except the last one. The food distribution was limited at $2, \mathrm{I} \mathrm{kg}$ per day.

The body composition was almost identical for a!l the animals, but the food conversion ratio was definitely in favour of the controls (3.01 compared with 3.21-3.58). The advantage of wheat bran at the lowest level was only partially recovered (FCR $=3.21$; other treatments : 3.46 - 3.58).

The author concludes that the addition of callulose to a " maize + soybean "diet is without any use ; a moderate level of wheat bran being however justified during the " pre-fattening " period.

\title{
UTILISATION DE L'ENSILAGE DE MAÏS GRAIN HUMIDE PAR LE PORC EN CROISSANGE ET FINITION
}

\author{
J. P. KERMOAL, M. L'AOT et J. P. LOSSEC \\ Maison de l'Élevage du Finistère, \\ $29 S$ - Quimper
}

\section{RÉSUMÉ}

3 régimes alimentaires à base d'orge, de maïs grain sec et d'ensilage de maïs grain humide broyé ont été comparés sur des porcs en croissance et finition (entre 35 et $100 \mathrm{~kg}$ ).

Les 3 régimes étaient équilibrés par un apport de tourteau de soja et d'un composé minéral vitaminisé.

Les porcs étaient alimentés suivant un plan de rationnement jusqu'à $60 \mathrm{~kg}$, ensuite la ration était constante. Les rations étaient calculées de manière à apporter la même quantité d'énergie digestible et de matières azotées totales pour les trois régimes.

Les deux régimes maïs se sont montrés identiques pour tous les critères étudiés (croissance, indice de consommation, composition corporelle).

Le régime orge a donné une croissance égale aux régimes mais, mais avec un indice de consommation $(\mathrm{kg} \mathrm{M} / \mathrm{kg}$ ) significativement plus élevé.

Les porcss nourris au régime orge avaient tendance à être plus maigres que ceux nourris aux régimes maïs.

\section{SUMMARY \\ UTILIZATION OF HUMID MAIZE GRAIN SILAGES \\ IN THE GROWING-FINISHING PIG}

3 food diets containing barley, dry maize grain and silages of grinded humid maize grain were compared in growing-finishing pigs (between 35 and roo $\mathrm{kg}$ ).

The 3 diets were balanced by a supply of soybean meal and a vitaminized mineral component. 